\title{
Conservation of Britain's biodiversity: Distribution and status of the Welsh endemic Hieracium britannicoides, Confused Hawkweed (Asteraceae)
}

\author{
Sarah J. Lee ${ }^{1}$; Wendy McCarthy ${ }^{2}$; Timothy C.G. Rich ${ }^{3 *}$ \\ ${ }^{1}$ Swansea, U.K. ${ }^{2}$ Llandudno, U.K. ${ }^{3}$ Cardiff, U.K. \\ *Corresponding author: Timothy C.G. Rich: tim rich@sky.com \\ This pdf constitutes the Version of Record published on $16^{\text {th }}$ February 2021

\begin{abstract}
Hieracium britannicoides, Confused Hawkweed, is a Welsh endemic plant confined to Caernarvonshire (v.c.49) and Denbighshire (v.c.50). Field surveys 2009-2019 indicate at least 390 plants occur in eight sites. The IUCN threat status is 'Vulnerable'. The main threats are spread of alien woody species (especially Cotoneaster), which without continued management will become a serious problem in the future, and over-grazing or spread of scrub from under-grazing.
\end{abstract}

Keywords: IUCN threat status, Wales.

\section{Introduction}

Hieracium britannicoides P. D. Sell, Confused Hawkweed, was first described as a species by Sell \& Murrell (2006) who separated it from other members of the $H$. britannicum group. Bevan (1990) gave the first detailed account of $H$. britannicoides (as H. britannicum) in Wales.

The history of the $H$. britannicum group may be briefly be summarised as follows (Bevan, 1990; Sell \& Murrell, 2006). Hanbury (1892) first described H. britannicum F. Hanb. and gave its distribution as Derbyshire (v.c.57), Staffordshire (v.c.39), mid-west Yorkshire (v.c.64), and possibly Fife (v.c.85). Further records followed including the first Welsh records in Caernarvonshire (v.c.49) (Linton, 1905). Subsequent studies showed there was significant variation within $\mathrm{H}$. britannicum, and it was split into a number of geographically separated species including two in North Wales: robust plants with spotted leaves were named as H. britanniciforme Pugsley (Pugsley, 1941) and the relatively small plants with unspotted leaves as $H$. britannicoides (Sell \& Murrell, 2006). Hieracium britannicum sensu stricto is now regarded as confined to Derbyshire and Staffordshire (Sell \& Murrell, 2006).

Hieracium britannicoides is characterised by having rosettes with ovate, obtuse rosette leaves with subtruncate bases often with retrorse teeth and sparsely hairy or glabrous above with few to numerous simple eglandular hairs beneath, the absence of stem leaves (or sometimes a very reduced \pm linear leaf), the few-headed inflorescences with 2-6 capitula, the involucral bracts with few to numerous stellate hairs (especially near the base), numerous dark glandular hairs and numerous simple eglandular hairs, 
and yellow styles (Figs. 1-3). Hieracium britannicoides is intermediate morphologically between $H$. britannicum and $H$. britanniciforme and has at separate times been included in both of them (Sell \& Murrell, 2006); it clearly merits its common name 'Confused Hawkweed'.

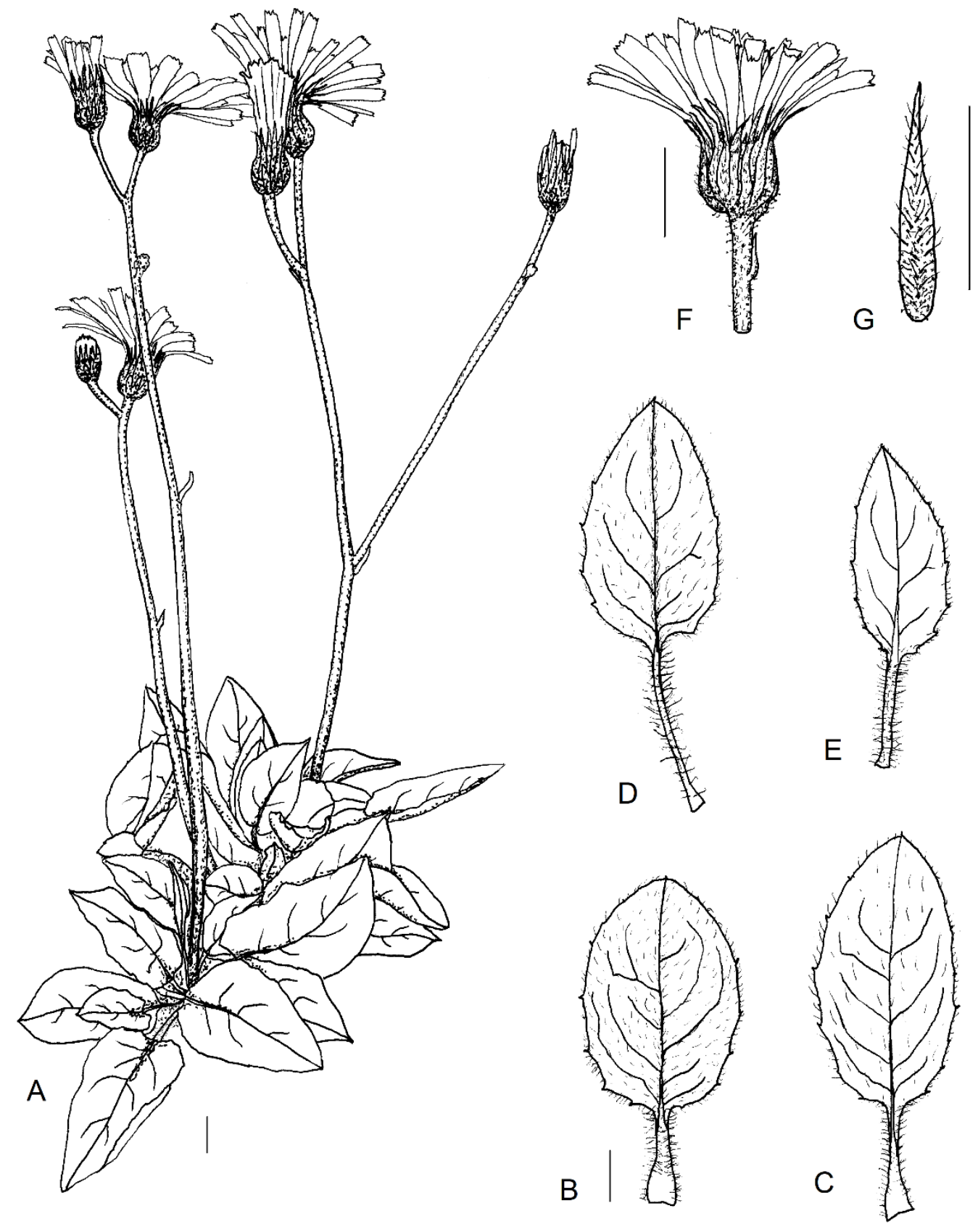

Figure 1. Hieracium britannicoides. A, plant. B-E rosette leaves; B and D lower sides, C and $E$ upper sides. F, capitulum. G, involucral bract. Scale bars $1 \mathrm{~cm}$. Del. T. Rich. 


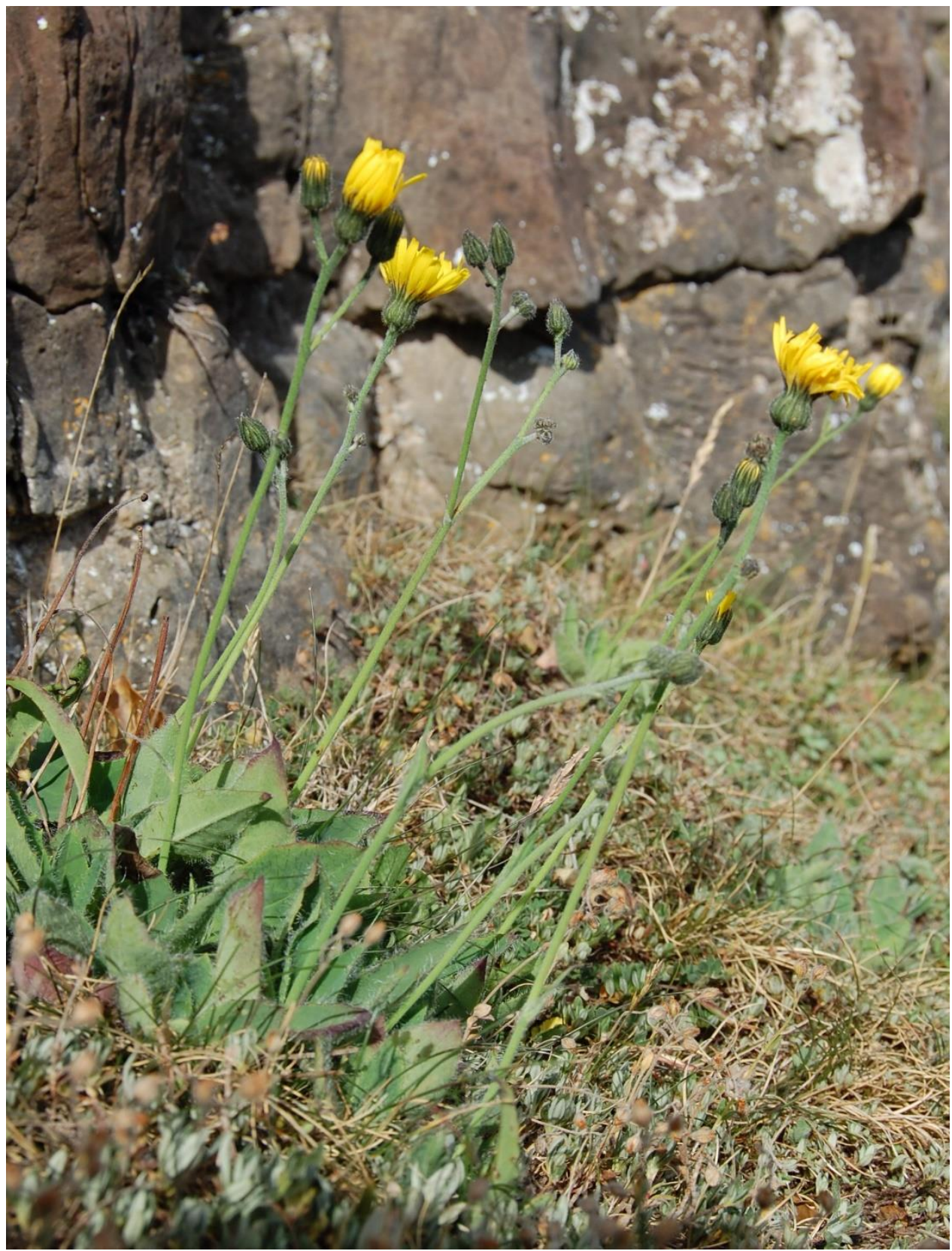

Figure 2. Hieracium britannicoides. Bryn Euryn (type locality)

In North Wales, $\mathrm{H}$. britannicoides is readily distinguished from $\mathrm{H}$. britanniciforme by its smaller size and the absence of spotting on the leaves. In a few sites it grows with $H$. vagense (F. Hanb.) Ley, which is normally easily distinguished by its laciniate leaves but some $H$. vagense plants in droughted habitats have small, lanceolate, acute more or less untoothed leaves which can then be distinguished by having dense glandular hairs and few simple hairs on the involucral bracts $(H$. britannicoides bracts are greyish-hairy due to the numerous simple hairs with white tips). Hieracium pseudoleyi (Zahn) Roffey also occurs with it on parts of the Great Orme and Little Orme; this is distinguished by its narrower leaves (Sawtschuk et al., 2008). 

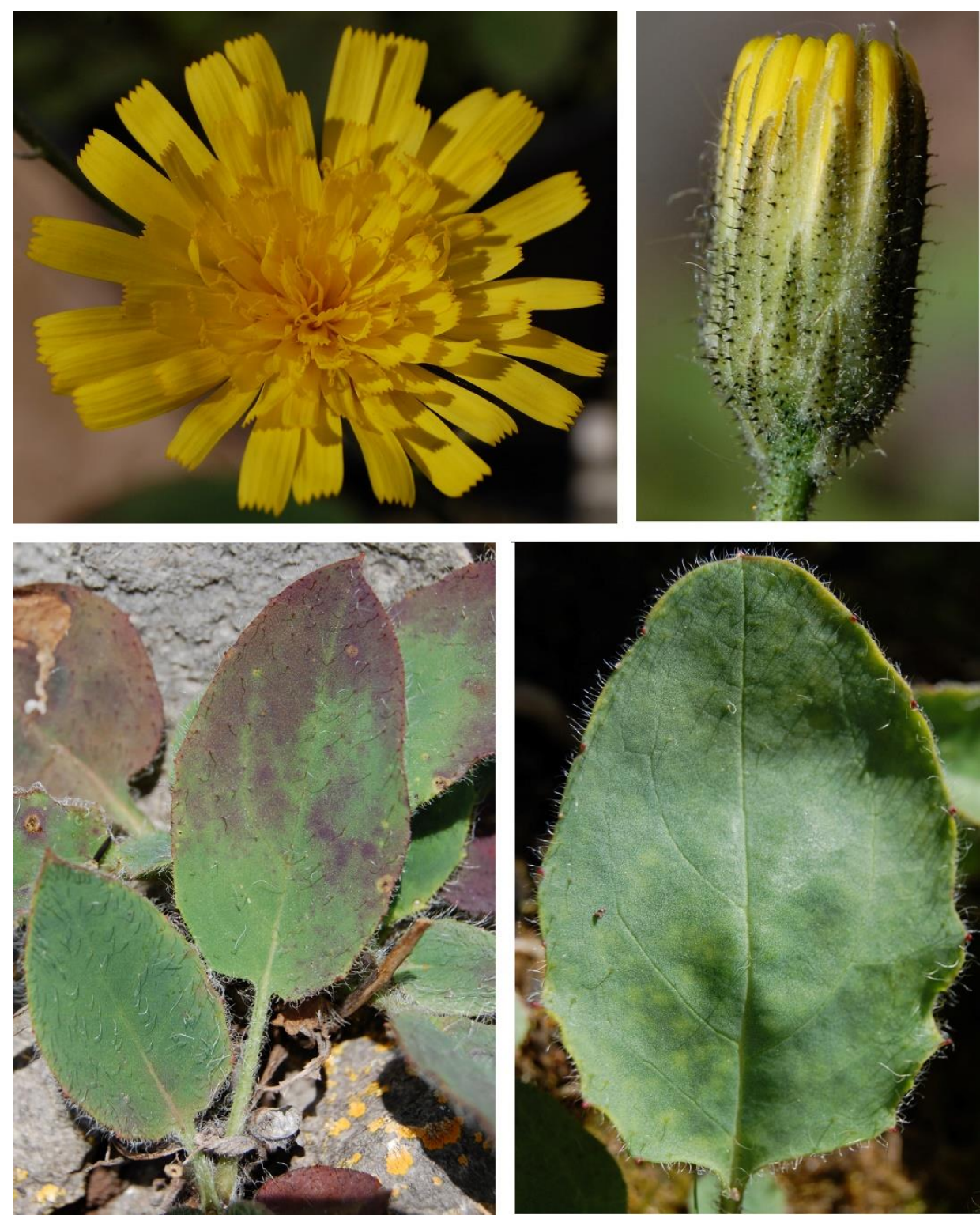

Figure 3. Hieracium britannicoides, details of heads, buds and leaves.

Since Bevan's (1990) account, a few more sites have been discovered. To assess the needs of $H$. britannicoides for conservation and to provide an IUCN Threat Category as required under the Global Plant Conservation Strategy (Secretariat for the Conservation of Biodiversity 2002), field surveys of the known sites were carried out in 2009-2011 by S. Lee (née Moore) with some recent updates by W. McCarthy. Further details are given by Moore (2009) and Rich (2010) and have been deposited with Natural Resources Wales, Conwy District Council and Denbighshire County Council.

\section{Methods}

Historical records were compiled from herbaria (BIRM, BM, CGE and NMW), the literature and David McCosh's Hieracium database (October 2020 version). Due to the 
historical confusion, the accepted distribution is based on critically determined herbarium specimens coupled with field observations by W. McCarthy and co-workers. The records were used to direct the field surveys in 2009-2011, and some 2019 data by W. McCarthy is also included.

The 'look-see' method (Hill et al. 2005) was adopted for data collection as it was the most appropriate method to survey the sites which had many inaccessible areas on cliffs, thus the population counts provide minimum population estimates. At each site, the location was recorded using GPS and the number of plants counted. Ecological notes on the vegetation types were made for most sites (here referenced in terms of British Plant Communities, Rodwell et al. 1991-2000).

\section{Results}

The historical records (Table 1 ) and field work indicate $H$. britannicoides occurred in eight sites in two vice-counties (Fig. 4) as follows, ordered approximately from west to east:

Pen-y-Gogarth (SH7584; v.c.49).

$32 \mathrm{H}$. britannicoides plants occurred on the cliffs immediately above the road with $\mathrm{H}$. britanniciforme in CG1 Festuca-Carlina/OV39 Asplenium spp. community.

Gogarth to Maes y Facrell Pen y Gogarth National Nature Reserve (SH7682 to SH7782; v.c.49).

At Gogarth, a large population of at least 99 plants occurs scattered across an extensive area of rocks and scarps in CG1 Festuca-Carlina grassland, with five plants recorded in open CG1 Festuca - Carlina and CG2 Festuca - Avenula grassland at the eastern end in the NNR.

Fferm (SH7980; v.c.49).

24 plants occurred on a cliff with $H$. vagense above Fferm.

Nant y Gamar (SH8081; v.c.49).

Surveys in 2016 and 2019 by W. McCarthy indicated at least 50-70 plants along the length of the cliff which is becoming overgrown with scrub in places. This may be the 1955 Bodafon site (Table 1).

Mynydd Pant (SH8181; v.c.49).

This site was first reported by Bevan (1990, as $H$. britannicum). At least 25 plants occurred over several tiers of north-facing cliffs in CG1 Festuca-Carlina/OV39 Asplenium spp. community.

Little Orme (SH8182; v.c.49).

One restricted population of five plants occurred on cliffs in vegetation transitional from MC4 Brassica maritime cliff to CG10 Festuca-Agrostis-Thymus grassland. 
Table 1. Historical records for $\boldsymbol{H}$. britannicoides.

\begin{tabular}{|c|c|c|c|}
\hline Locality & Date & Collector & Source \\
\hline \multicolumn{4}{|l|}{ Bodafon (v.c.49) } \\
\hline Bodafon & 17 July 1955 & - & BIRM \\
\hline \multicolumn{4}{|l|}{ Great Orme (v.c.49) } \\
\hline Great Orme & $\begin{array}{l}\text { July \& August } \\
1871\end{array}$ & S. H. Bickham & CGE \\
\hline Great Orme & 9 July 1890 & E. F. Linton & BM \\
\hline Great Orme & August 1890 & S. H. Bickham & BM \\
\hline Great Orme & August 1894 & J. E. Griffith & CGE \\
\hline Great Orme & $\begin{array}{l}\text { 4 September } \\
1902\end{array}$ & H. W. Pugsley & BM \\
\hline Great Orme & 6 July 1905 & H. W. Pugsley & BM \\
\hline Great Orme & 22 June 1907 & A. Ley & $\begin{array}{l}\text { BM, } \\
\text { NMW }\end{array}$ \\
\hline $\begin{array}{l}\text { Great Orme, exposed } \\
\text { limestone rocks on SW side }\end{array}$ & 9 July 1912 & $\begin{array}{l}\text { E. S. Marshall \& } \\
\text { W. A. } \\
\text { Shoolbred }\end{array}$ & BM, CGE \\
\hline $\begin{array}{l}\text { Great Orme, on a stony } \\
\text { knoll }\end{array}$ & $\begin{array}{l}9 \text { July } \& 18 \\
\text { August } 1912\end{array}$ & S. H. Bickham & CGE \\
\hline Great Orme, Gloddaeth & June 1922 & A. Ley & NMW \\
\hline Great Orme & 23 June 1931 & T. J. Foggitt & BM \\
\hline \multicolumn{4}{|l|}{ Little Orme (v.c.49) } \\
\hline Little Orme & July 1891 & J. E. Griffith & BM \\
\hline Little Orme & July 1893 & J. E. Griffith & CGE \\
\hline Little Orme, lime rocks & 19 June 1901 & A. Ley & CGE \\
\hline \multicolumn{4}{|l|}{ Mynydd Pant (v.c.49) } \\
\hline Mynydd Pant & 13 May 1988 & J. Bevan & Herb. JB. \\
\hline \multicolumn{4}{|l|}{ Bryn Euryn (v.c.50) } \\
\hline Bryn Euryn & May 1867 & A. Ley & NMW \\
\hline Bryn Euryn & $\begin{array}{l}16 \text { September } \\
1889\end{array}$ & F. J. Hanbury & NMW \\
\hline Bryn Euryn & May 1967 & W. E. Hughes & NMW \\
\hline $\begin{array}{l}\text { Bryn Euryn, in cracks in } \\
\text { south-facing limestone } \\
\text { cliffs }\end{array}$ & 15 June 1968 & J. M. Brummitt & $\begin{array}{l}\text { CGE } \\
\text { (holotype) }\end{array}$ \\
\hline Bryn Euryn & 16 July 1969 & J. M. Brummitt & NMW \\
\hline \multicolumn{4}{|l|}{ Llysfaen (v.c.50) } \\
\hline Llysfaen & 17 June 1975 & J. M. Brummitt & NMW \\
\hline $\begin{array}{l}\text { Llysfaen, above the new } \\
\text { inn in old quarry }\end{array}$ & 1 June 1979 & J. M. Brummitt & NMW \\
\hline
\end{tabular}


Bryn Euryn Local Nature Reserve (SH8379; v.c.50).

This is the type locality. Hieracium britannicoides occurred in abundance on the southfacing cliffs; 99 plants occurred in CG1 Festuca-Carlina grassland.

Mynnydd Marian Nature Reserve, Llysfaen (SH8977; v.c.50).

At least 61 plants occurred in scrappy CG3 Bromus grassland on the rocky edges at the top of the quarry cliff, with some plants on the quarry faces. No plants were found on adjacent rocks at Ty Mawr (SH8877) or above Isallt (SH8976).

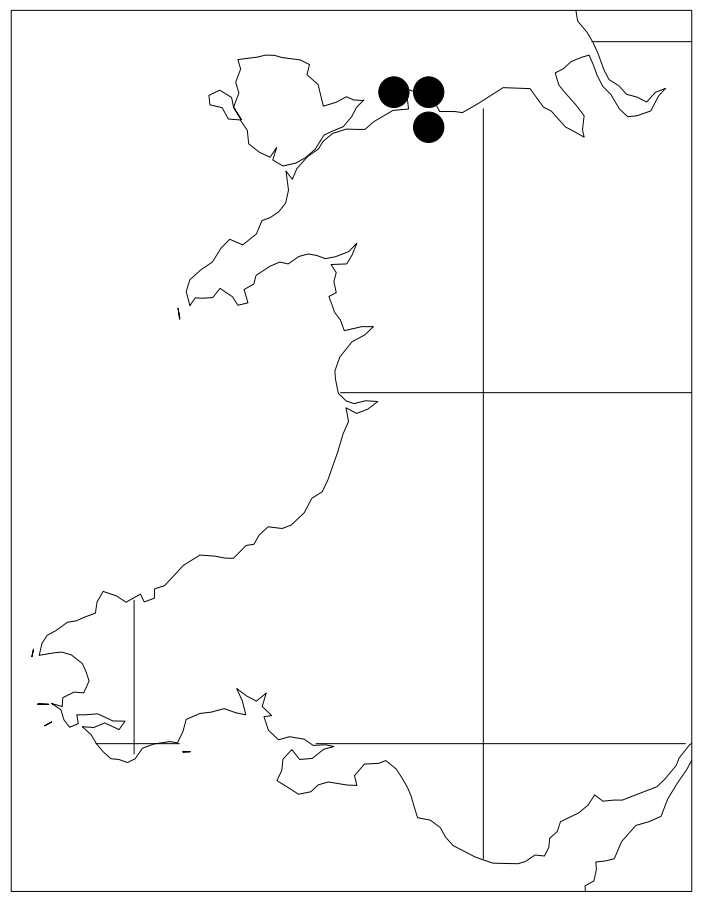

Figure 4. Distribution map of Hieracium britannicoides.

\section{Discussion}

The field surveys have shown that at least 390 plants of $H$. britannicoides occurred in eight sites in Caernarvonshire (v.c.49) and Denbighshire (v.c.50). Overall, $H$. britannicoides is assessed under the IUCN (2001) threat criteria as 'Vulnerable'.

All of the sites are on Carboniferous Limestone on cliffs, in old quarries and in grassland. The vegetation is short and open, and is usually typical of crevice and ledge vegetation or of open calcicolous grasslands. The larger populations occurred on southfacing rocks in thermophilous conditions, but plants also occurred on north-facing cliffs at Pen-y-gogarth, Mynydd Pant and Nant y Gamar.

Like its relatives, $H$. britannicoides is likely to be a polycarpic and apomictic but this has not been tested experimentally. It typically flowers in May and June, sometimes extending into July and occasionally again in the autumn. $49 \%$ of the plants seen in 2010 were flowering or fruiting; seed set appeared to be high. 
All of the populations occur in sites designated as Sites of Special Scientific Interest (SSSI) and some were in nature reserves or Special Areas for Conservation (SAC). There was no evidence for loss of sites or decline and the species appears stable. The only immediate threat is the spread of alien woody species such as Cotoneaster microphyllus and Quercus ilex, both of which can grow on the limestone rocks and shade the hawkweeds. Extensive work has already been carried out to control these alien plants at Bryn Euryn, Great Orme, Little Orme and Mynnydd Marian; without continued management these will become a serious problem in the future for H. britannicoides and the many other rare plants which occur in this area.

As most populations occur on relatively inaccessible cliffs, grazing mainly restricts populations to steep areas out of the reach of sheep and goats. Hawkweeds in general are highly palatable and consequently sensitive to over-grazing by stock. Grazing may be a key part of site management and it is likely that any stock grazing during the growth season (c. March to October) will eliminate it from accessible areas. The smallest population is on the Little Orme which is also the most heavily sheep-grazed site. It is unclear if the goats on the Great Orme eat it. In contrast, on the steep northfacing cliffs at Mynydd Pant and Nant y Gamar it is at longer term risk from scrub/woodland invasion which may eventually shade out the plants.

Seeds of $H$. britannicoides have been collected from the Great Orme with consent and deposited in the Millennium Seed Bank for ex situ conservation.

\section{Acknowledgements}

We would like to thank Jim Bevan, Helen Jowett, David McCosh, John Osley, Heledd Wyn Jones, Conwy County Borough Council, Natural Resources Wales, and the Keepers for access to herbaria.

\section{References}

Bevan, J. 1990. Hieracium britannicum F. J. Hanb. in Wales. Watsonia 18: 199-200. http://archive.bsbi.org.uk/Wats18p199.pdf

Hanbury, F. J. 1892. Further studies on Hieracia new to Britain. Journal of Botany 30: 366-370.

Hill, D., Fasham, M., Tucker, G., Shewry, M. \& Shaw, P., eds. 2005. Handbook of Biodiversity Methods. Survey, evaluation and monitoring. Cambridge: Cambridge University Press.

IUCN 2001. IUCN Red list categories and criteria. Version 3.1. Gland, Switzerland: International Union for Conservation of Nature.

Linton, W. R. 1905. An account of the British Hieracia. London: West, Newman \& Co.

Moore, S. J. 2009. Distribution and current status of three Welsh endemic Hawkweeds: Hieracium breconicola, Hieracium britannicoides and Hieracium subbritannicum. MSc. thesis, University of Glamorgan, Pontypridd, September 2009.

Pugsley, H. W. 1941. New species of Hieracium in Britain. Journal of Botany 79: 177197.

Rich, T. C. G. 2010. Hieracium britannicoides survey update 2010. Unpublished report, National Museum of Wales, Cardiff, July 2010. 
Rodwell, J. S., ed. 1991-2000. British plant communities. 5 volumes. Cambridge: Cambridge University Press.

Sawtschuk, J., McCarthy, W. \& Rich, T. C. G. 2008. Conservation of Britain's biodiversity: Hieracium pseudoleyi (Asteraceae), Purple-flushed Hawkweed. Watsonia 27: 59-64.

Secretariat for the Conservation of Biodiversity 2002. Global strategy for plant conservation. Montreal: Secretariat for the Conservation of Biodiversity.

Sell, P. D. \& Murrell, G. 2006. Flora of Great Britain and Ireland. Volume 4. Cambridge: Cambridge University Press.

Copyright retained by author(s). Published by BSBI under the terms of the Creative Commons Attribution 4.0 International Public License.

ISSN: $2632-4970$

https://doi.org/10.33928/bib.2021.03.065 